\title{
Effects of irrigation and green manure on corn (Zea mays L.) biomass and grain yield
}

\author{
Aikaterini Karyoti ${ }^{1,2^{*}}$, Dimitris Bartzialis $^{1}$, Maria Sakellariou-Makrantonaki ${ }^{1}$, Nikolaos \\ Danalatos $^{1}$
}

${ }^{1}$ University of Thessaly, School of Agricultural Sciences, Department of Agriculture Crop Production and Rural Environment, Fytokou Str, 384 46, Volos, Greece. ${ }^{2}$ Hellenic Agricultural Organization "Demeter" - Soil and Water Resources Institute, Sindos, Greece. *Corresponding author: mail@6dim-laris.lar.sch.gr

\begin{abstract}
The effect of green manure on the growth of irrigated corn (Zea mays L. cv Cisko) was investigated under different drip irrigation rates on a clay soil in Greece. A feed pea (Pisum sativum L. cv Olympus) crop was established in autumn and incorporated into the soil in spring, about 3 weeks before the sowing of the subsequent corn. During the growing period, the growth stages and yield of corn were assessed under three drip irrigation levels I1 (33\% low), I2 (66\% moderate) and I3 (100\% full of actual evapotranspiration, ETm) and two cultivation practices a) application of green manure and b) experiment without previous green manuring. The positive effects of green manuring were greater in the moderately and fully irrigated plots. Drip irrigation was applied to minimize nitrate leaching which requires low volume of water. In plots receiving moderate or full irrigation, biomass, leaf area index (LAI) and seed yield were much higher in comparison to stressed plants (33\% ETm). Increased yield and dry biomass obtained in the plots after incorporation of feed pea residues, may be attributed mainly to the elevated amount of soil organic matter (SOM). The increased yield exceeds the overall cost for green manure application, and this economic incentive is expected to be even more significant taking into account the continuous improvement of soil conditions.
\end{abstract}

Keywords: Irrigation, green manure, cover crop, fertilization 


\section{Introduction}

Modern agricultural production in Mediterranean countries is largely based on monoculture of single species plantations taking advantage of scale economy for maximizing farmer profit. However, the significant reduction of biodiversity and organic system controls in such cropping systems are associated with adverse environmental outputs and eventually land degradation that must be alleviated before irreversible levels (desertification) may be reached.

Major issue of monoculture comprises the depletion of soil organic carbon (SOC) (Reganold et al., 1987; El Titi, 1990; Tilman, 1998; Wander et al., 1998; Kätterer and Andrén, 1999; Smith,1999; Tebruegge, 1999; FiBL, 2000; ), whereas in Mediterranean lowlands with modest runoff (and soil erosion) and deep percolation, depletion of SOC is largely due to organic matter mineralization as well as oxidation (Reicosky and Lindstrom, 1995; Lal, 1997; Paustian et al., 1998a,b; FAO, 2001). Besides SOC depletion, monocultures bring about accelerated soil structural stability and inherent fertility degradation. Topsoil structure degradation and SOC reduction to the present low levels $(<1 \%)$ are also the result of extensive monoculture of winter cereals and irrigated cotton crops in the Thessaly plain, the largest Greek lowland and the center of the country's agricultural production.

Many authors have demonstrated the paramount importance of crop rotation and green manuring in alleviating the negative effects of monoculture and improving soil physical properties (bulk density, porosity), soil structure and water holding capacity, SOC and nutrient availability (Bremer, 1960; FAO, 2010; Skoufogianni et al., 2013) as well as the reduction of $\mathrm{N}$ losses through runoff, leaching and soil erosion. In particular, green manuring with legumes greatly improves soil fertility by increasing SOC and nitrogen due to biological fixation of atmospheric nitrogen.
Thus green manuring with legumes may reduce the required amount of nitrogen fertilizer by $100-200 \mathrm{~kg}$ $\mathrm{N} \mathrm{ha}^{-1}$ (Helming et al., 2014) drastically reducing production costs.

A relatively recent 3-year field study carried out by Skoufogianni et al (2013) highlighted the positive effect of field pea as a winter cover crop recorded on the seed yield of a fully irrigated maize crop on a clay soil of Thessaly plain (central Greece), under different nitrogen dressings. Feed pea as green manure enriched the topsoil with $180-220 \mathrm{~kg} \mathrm{~N}^{-1}$ annually, after incorporation (Skoufogianni et al., 2013), and brought about a significant increase in both nitrogen mineralization and fertilization efficiency as well as maximum yields. However, elongation of the linear part of the yield-uptake relation was also apparent, reflecting a higher yield potential for the plots receiving green manure. This demonstrates the improvement of soil physical characteristics and water use efficiency, which could not fully understood without including different (irrigation) water application levels in the comparison. The present work is aiming to study the effect of green manure (feed pea) on the growth and yield potential of maize on the above same clay soil under different irrigation applications, while maintaining fertilization and the rest cultivation practices at optimum levels for crop production.

\section{Materials and Methods}

A split plot field experiment with three replicates (blocks) was established on a clay soil in the Experimental Farm of the University of Thessaly situated in Velestino (Magnesia) in central Greece (coordinates: $39^{\circ} 2^{\prime} \mathrm{N}, 22^{\circ} 45^{\prime} \mathrm{E}$, $70 \mathrm{~m}$ above sea level). Based on main characteristics, soil colour, parent material, soil structure development and partial leaching of carbonates, according to the World 
Reference Base for Soil Resources (Working Group WRB, 2006) studied soils have been classified as Calcaro vertic Cambisol (CMvr).

Soil samples were taken from two depths (0-30 and 30-60 cm) for determination of particle size distribution, bulk density, cation exchange capacity(CEC), $\mathrm{pH}$, exchangeable $\left(\mathrm{K}^{+}\right)$, organic matter content, $\mathrm{CaCO}_{3}$ content and available P-Olsen). Nitrates were determined by a FIAstar 9000 Analyzer (FOSS TECATOR, Sweden).

According to the experimental protocol, feed pea (variety "Olympus") was sown in October, 2015 and grew during the winter and spring period, and finally it was incorporated (green manure) into the soil in April 2016. Then the soil was prepared and sown again with maize $(8 / 5 / 2016)$. The crop emerged on May $15^{\text {th }}$ and grew during the summer period to be finally harvested in first week of September, 2016. Weed, pest and disease control and optimum NPK fertilization for maximum maize yields were applied. Irrigation was applied at three levels, i.e. 33\%, 66\% and $100 \%$ of actual evapotranspiration (ETm), comprising the main plots (Sakellariou-Makrantonaki and Vagenas, 2006). The subplots comprised the two cultivation practices considered: a) with green manure, b) without green manure.

Green manuring took place a few days after the blooming of the feed pea. Just before its incorporation, samples from the aerial biomass were collected from 3 representative sites, and prepared for laboratory plant analysis: the samples were weighted, dried at $65^{\circ} \mathrm{C}$ for $48 \mathrm{~h}$, and then pulverized and weighted again tocalculate the quantity of dry biomass which was incorporated into the soil. Finally, the samples were analyzed for total nitrogen content using the standard Kjeldahl method (Nelson \& Sommers, 1973).
Mean daily weather data were collected in a fully automatic meteorological station installed in the experimental field. A standard class-A evaporation pan was also installed to determine potential evapotranspiration (ETo) using the pan coefficients according to the actual weather conditions (0.75-0.8). The, maximum crop water needs (ETm) were determined using the formula $\mathrm{ETm}=\mathrm{ETo} \mathrm{x} \mathrm{kc}$, where $\mathrm{kc}$ the crop coefficient of corn taking values from 0.4 to 1.1 , according to FAO (1998).

The experimental area is generally characterized by a typical Mediterranean climate with cool humid winters and hot dry summers. In particular, the growing period of maize (May-end August) in 2016 was characterized by mean air temperature about $26.5^{\circ} \mathrm{C}$ and can be considered as drier and slightly warmer than average, due to a warm-dry spell prevailing in early to mid-June. However, the post flowering period was characterized by average air temperatures so that grain filling period and maturation were not adversely affected. The amount of rainfall during the growing period (June end August) was modest (only $11.0 \mathrm{~mm}$ ) so that irrigation comprised practically the main water input for the different treatments (Table 1). The rest cultivation practices (fertilization, weed, pest and disease control) were kept optimum for obtaining potential production. For ensuring better accuracy of the water inputs, a drip irrigation system was used applying water at 7-9 day intervals according to Table 1 . The soil moisture availability needed to determine the crop water requirements and irrigation application time and depth moisture was recorded using six customized access tubes of the Diviner 2000 (Sentek Co.). These had been installed in the experimental field allowing logging and storing soil moisture recordings at $10 \mathrm{~cm}$ soil depth intervals down to $1 \mathrm{~m}$ depth from the soil surface. 
Table 1. Irrigation schedule of maize in the experimental field (Velestino, 2016).

\begin{tabular}{cccc}
\hline & I1(33\%) & I2(66\%) & I3(100\%) \\
\cline { 2 - 4 } Irrigation dates & \multicolumn{3}{c}{ Consumed Irrigation Water } \\
(mm) \\
\hline Sowing date & 30.0 & 30.0 & 30.0 \\
22 June & 26.4 & 52.8 & 79.2 \\
30 June & 17.6 & 35.2 & 52.8 \\
7 July & 17.6 & 35.2 & 52.8 \\
16 July & 26.5 & 47.0 & 70.4 \\
24 July & 17.6 & 35.2 & 52.8 \\
1 August & 20.5 & 41.1 & 61.6 \\
8 August & 17.6 & 35.2 & 52.8 \\
16 August & 20.5 & 41.1 & 61.6 \\
23 August & 17.6 & 35.2 & 52.8 \\
TOTAL & $\mathbf{2 1 1 . 9}$ & $\mathbf{3 8 8 . 0}$ & $\mathbf{5 6 6 . 8}$ \\
\hline
\end{tabular}

Taking into account the amount of rainfall during growing period (June - end August), plants have finally received $222.9 \mathrm{~mm}, 399.0 \mathrm{~mm}$ and $577.8 .0 \mathrm{~mm}$ of water, for the respective treatments I1(33\%), I2(66\%) and $\mathrm{I} 3(100 \%)$

Actually, the nitrogen applied to moderately and fully irrigated plots slightly exceeded to $350 \mathrm{~kg} \mathrm{ha}^{-1}$ supplied in two equal applications (basal dressing with ammonium phosphate and a top-dressing with ammonium nitrate). The dry plots received only $250 \mathrm{~kg} \mathrm{ha}^{-1}$. The growth of maize by means of plant height, leaf area index (LAI), fresh and dry matter per plant organ were measured using destructing samples periodically taken during the growing period and upon harvest. All plant samples, including samples of the legume crop before its incorporation were transferred to the laboratory, for chemical determinations. After drying, the samples were blended and analyzed for total nitrogen $\left(\mathrm{N}_{\text {tot }}\right)$ using the standard Kjeldahl method. Here, the final results at harvest are presented and discussed. The data were statistically analyzed using analysis of variance through the GENSTAT Software (Payne et al., 2011). Means were compared using revised LSD test at 0.05 levels.

\section{Results}

Table 2 summarizes the main physical and chemical properties of the study soil at two depths viz. 0-30 $\mathrm{cm}$ and $30-60 \mathrm{~cm}$. The soil is slightly calcareous, clay textured with a high CEC in both depths and a higher SOC and SOM and Ntot contents in the surface horizon, Ap. Furthermore, increased $\mathrm{P}$ and $\mathrm{K}$ contents were measured in the topsoil $(0-30 \mathrm{~cm})$, attributable to residual effect from $\mathrm{P}-\mathrm{K}$ fertilization in previous years. The soil is well suitable for cultivation with annual crops such as corn (Zea mays L.), cotton (Gossypium hirsutum L.) and alfalfa (Medicago sativa L.). 
Table 2. Measured physical and chemical properties of the study soil.

\begin{tabular}{|c|c|c|c|c|c|c|c|c|c|c|c|c|}
\hline \multirow{2}{*}{$\begin{array}{c}\text { Soil layer } \\
\text { depth } \\
\text { (cm) }\end{array}$} & \multicolumn{3}{|c|}{ particle size } & \multirow[t]{2}{*}{ texture } & \multirow[t]{2}{*}{ BD } & \multirow{2}{*}{\begin{tabular}{c|} 
CEC \\
$\mathrm{cmol} \mathrm{kg}^{-1}$
\end{tabular}} & \multirow[t]{2}{*}{$\mathrm{pH}$} & \multirow{2}{*}{\begin{tabular}{l|} 
Corg. \\
$\mathrm{g} \mathrm{kg}^{-1}$
\end{tabular}} & \multirow{2}{*}{$\begin{array}{c}\mathbf{N} \\
\mathrm{g} \mathrm{kg}^{-1}\end{array}$} & \multirow{2}{*}{$\begin{array}{c}\mathbf{O M} \\
\%\end{array}$} & \multirow{2}{*}{$\begin{array}{c}\mathrm{CaCO}_{3} \\
\%\end{array}$} & \multirow{2}{*}{$\begin{array}{c}\mathbf{P} \\
\mathrm{g} \mathrm{kg}^{-1}\end{array}$} \\
\hline & $\begin{array}{r}\text { Sand } \\
(\%)\end{array}$ & $\begin{array}{l}\text { Silt } \\
(\%)\end{array}$ & $\begin{array}{l}\text { Clay } \\
(\%)\end{array}$ & & & & & & & & & \\
\hline & 26.3 & 33.9 & 39.7 & Clay & 1.28 & 28.2 & 7.6 & 14.51 & 1.66 & 2.90 & 7.46 & 19.8 \\
\hline $30-60$ & 25.4 & 32.6 & 42.0 & Clay & 1.27 & 25.5 & 7.8 & 8.67 & 1.02 & 1.73 & 8.62 & 3.4 \\
\hline
\end{tabular}

BD: bulk density, CEC:cation exchange capacity, $\mathrm{C}_{\text {org }}$. organic carbon, $\mathrm{N}$ : total nitrogen, OM: organic matter

The mean concentration of nitrates in the irrigation water was $21.4 \mathrm{mg} \mathrm{L}^{-1}$, and after conversion to nitrogen the content (multiplying by 0.2259 ) was $4.83 \mathrm{~N}$ $\mathrm{mg} \mathrm{L}^{-1}$. The amount of irrigation water per each treatment and the nitrates content were also used (Table 3) to calculate the nitrate nitrogen inputs.

Table 3. Total inputs of nitrogen for each irrigation treatment

\begin{tabular}{ccc}
\hline Treatment & $\begin{array}{c}\text { Water used for irrigation } \\
(\mathbf{m m})\end{array}$ & $\begin{array}{c}\mathbf{N O}_{3}{ }^{-\mathbf{N}} \\
\mathbf{k g ~ h a}^{-1}\end{array}$ \\
\hline $\mathbf{I 1}$ & 211.9 & 10.2 \\
$\mathbf{I 2}$ & 388.0 & 18.7 \\
$\mathbf{I 3}$ & 566.8 & 27.4 \\
\hline
\end{tabular}

Concerning the green manure, the mean dry biomass of feed pea was found $0.52 \mathrm{~kg} \mathrm{~m}^{-2}$ which corresponds to $5.2 \mathrm{t} \mathrm{ha}^{-1}$. Results have showed that green manure crops provide a significant source of total $\mathrm{N}$ and $\mathrm{K}$. The quantity of incorporated phosphorus $(\mathrm{P})$ into the soil was much lower but is not negligible to the subsequent crop. The incorporated quantity of nutrients was $157 \mathrm{~kg} \mathrm{ha}^{-1}$ for $\mathrm{K}, 107.1 \mathrm{~kg} \mathrm{ha}^{-1}$ for $\mathrm{N}$ and $\mathrm{P}$ was only $7.8 \mathrm{~kg} \mathrm{ha}^{-1}$.
The results on final crop (corn) performance are presented in Table 4 for the various treatments under study. As expected, irrigation significantly affected corn crop growth as reflected by plant height. As apparent in Table 4, the final plant height reached 1.83 $\mathrm{m}$ for both, full and moderate irrigation treatments (100\%-66\% ETm), while the stressed plants $(33 \%$ ETm) did not exceed $1.5 \mathrm{~m}$ in height. On the contrary, the final height of maize plants did not vary between the green manured and the control plants (Table 4). 
Table 4. The impact of different irrigation levels and green manure on maize yield.

\begin{tabular}{|c|c|c|c|c|c|c|c|c|c|c|c|c|c|}
\hline \multirow[t]{2}{*}{ Maize } & \multicolumn{4}{|c|}{ IRRIGATION } & \multicolumn{3}{|c|}{ GREEN MANURE } & \multicolumn{6}{|c|}{ IRRIGATION $x$ GREEN MANURE } \\
\hline & I3 & 12 & I1 & $L S D$ & + & - & $L S D$ & I3+ & I3- & I2 & I2- & I1+ & I1- \\
\hline $\begin{array}{l}\text { height } \\
(\mathrm{cm})\end{array}$ & 1.83 & 1.7 & 1.5 & 0.21 & 1.6 & 1.7 & ns & 1.7 & 1.8 & 1.7 & 1.8 & 1.5 & 1.5 \\
\hline $\begin{array}{l}\text { dry/fresh } \\
\text { biomass }\end{array}$ & 0.80 & 0.79 & 0.80 & $n s$ & 0.79 & 0.81 & ns & 0.81 & 0.78 & 0.75 & 0.83 & 0.79 & 0.81 \\
\hline $\begin{array}{l}\text { *DB leaves } \\
\left(\mathrm{g} \mathrm{m}^{-2}\right)\end{array}$ & 450.0 & 466.5 & 287.5 & 63 & 430.2 & 372.4 & 51.3 & 484.1 & 415.8 & 508.5 & 424.4 & 297.9 & 277.1 \\
\hline $\begin{array}{l}\text { DB of cobs } \\
\left(\mathrm{g} \mathrm{m}^{-2}\right)\end{array}$ & 1247.0 & 1292.7 & 796.8 & 174 & 1192.2 & 1032.1 & 142.2 & 1341.7 & 1152.2 & 1409.2 & 1176.2 & 825.5 & 768.0 \\
\hline $\begin{array}{l}\text { DB of shoots } \\
\left(\mathrm{g} \mathrm{m}^{-2}\right)\end{array}$ & 320.8 & 332.6 & 205.0 & 44.9 & 306.7 & 265.5 & 36.58 & 345.2 & 296.4 & 362.6 & 302.6 & 212.4 & 197.6 \\
\hline $\begin{array}{l}\text { Total DB } \\
\left(\mathrm{g} \mathrm{m}^{-2}\right)\end{array}$ & 2017.7 & 2091.8 & 1289.2 & 282 & 1929.0 & 1670.1 & 230.0 & 2171.1 & 1864.4 & 2280.3 & 1903.2 & 1335.8 & 1242.7 \\
\hline $\begin{array}{l}\text { DB ratio } \\
\text { shoots/total }\end{array}$ & 0.164 & 0.173 & 0.141 & $n s$ & 0.162 & 0.157 & $n s$ & 0.163 & 0.164 & 0.188 & 0.157 & 0.134 & 0.149 \\
\hline
\end{tabular}

*DB: dry biomass

Concerning biomass production and seed yield performance, the plots receiving moderate to full irrigation exceeded $20 \mathrm{t} \mathrm{ha}^{-1}$ in dry biomass whereas the stressed plants (33\% ETm) did not exceed $12.9 \mathrm{t} \mathrm{ha}^{-1}$ (LSD0.05 $=282 \mathrm{~kg} \mathrm{str}^{-1}$ - see also Figure 1). Similarly, yields reached $12.5-13 \mathrm{t} \mathrm{ha}^{-1}$ in the moderate and full-irrigated plants, but did not exceed $8 \mathrm{tha}^{-1}$ in the stressed plants. As presented in Table 4, important plant traits such as the dry/fresh ratio (about $80 \%$ ) and the dry matter distribution of the various plant organs (dry leaves, shoots and cobs) did not vary significantly among the various treatments.

As can be depicted from Figure 2 and Table 4 the plots receiving moderate to full irrigation performed by 2 $\mathrm{t}$ ha $\mathrm{a}^{-1}$ higher grain yields and by 3.1-3.8 $\mathrm{t} \mathrm{ha}^{-1}$ higher total dry biomass. 


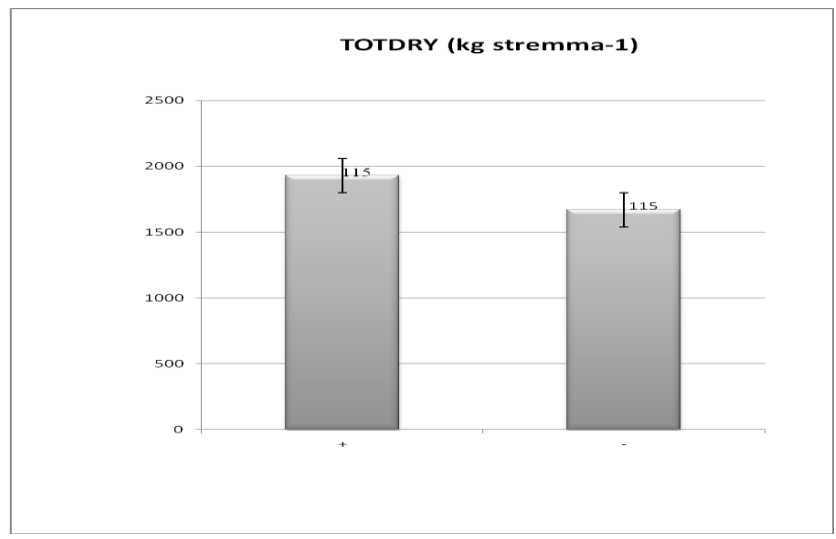

a) addition (+) or not (-) of green manure with pea before corn sowing

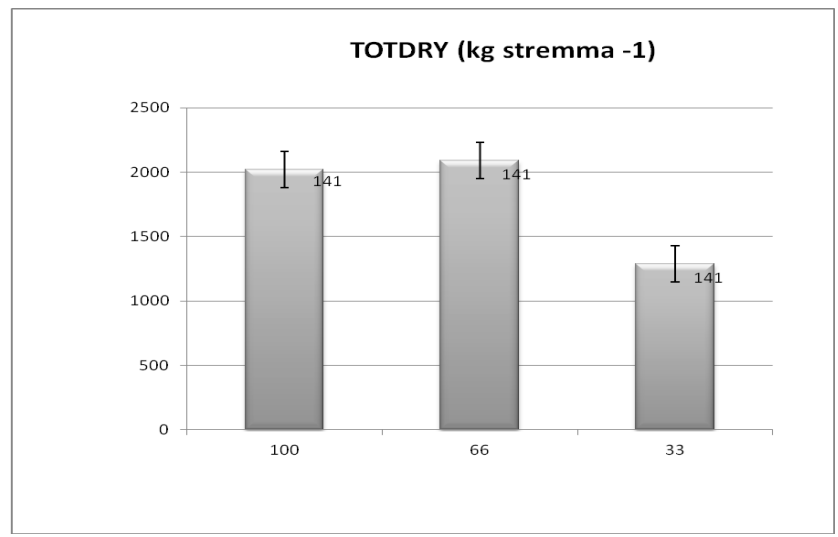

b) the three irrigation levels $(100 \%, 66 \%, 33 \%$ ETm)

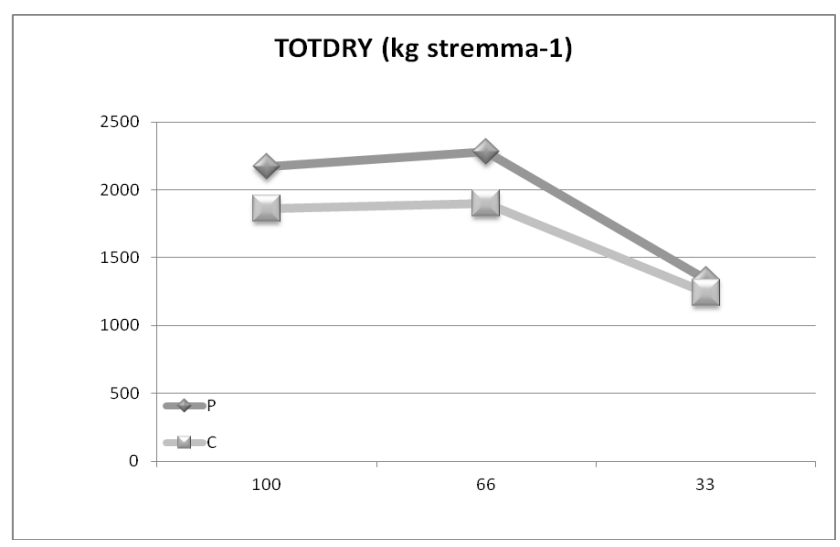

c) the above in combination $(\mathrm{P}=$ pea, $\mathrm{C}=$ control $)$

Figure 1. Total aerial dry corn biomass (Vertical bars present values of Least Significant Differences (LSD) at 5\% probability level *stremma) 


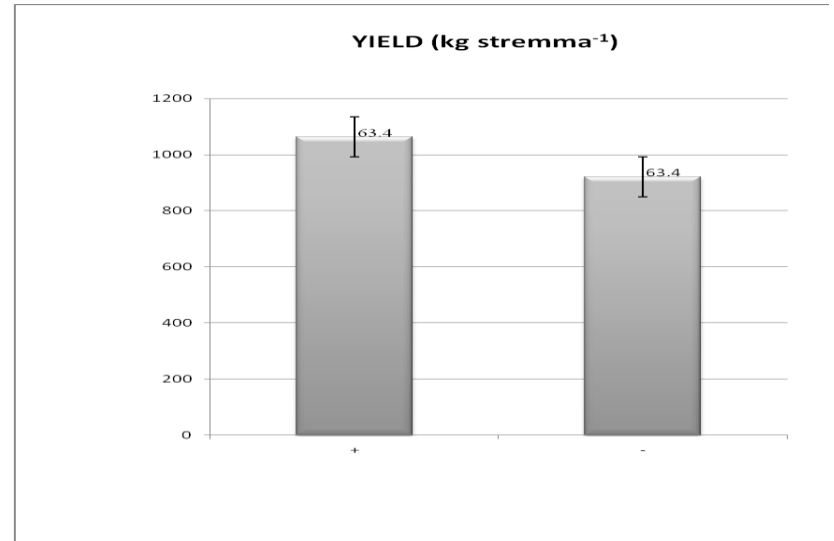

a) addition $(+)$ or not $(-)$ of green manure with pea before corn sowing

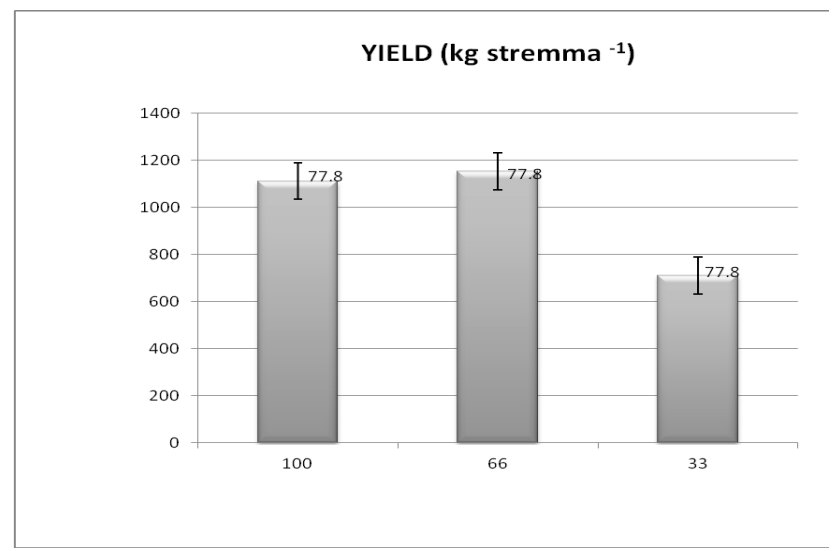

b) the three irrigation levels $(100 \%, 66 \%, 33 \% \mathrm{ETm})$

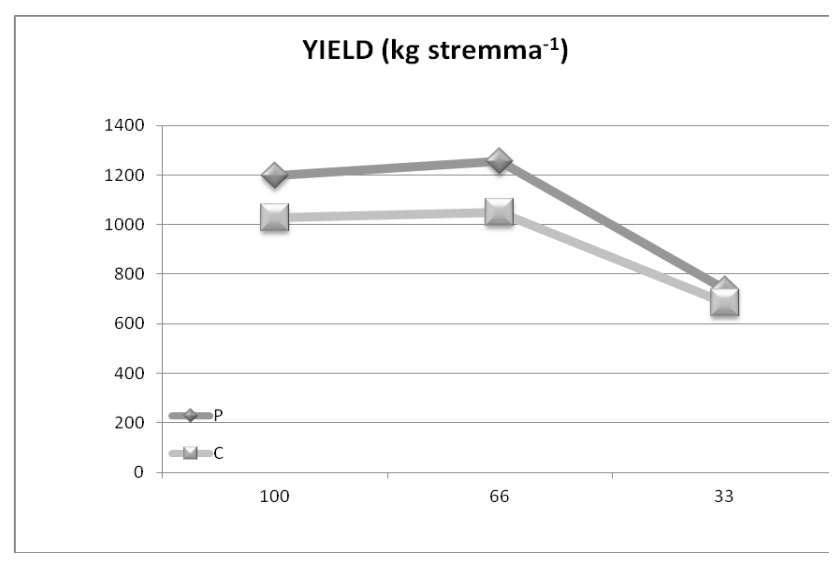

c) the above in combination $(\mathrm{P}=$ pea, $\mathrm{C}=$ control $)$

Figure 2. Grain yield up grain yield on harvest (The yields are expressed assuming grain moisture content $15 \%$, Vertical bars present values of LSD at $5 \%$ probability level *stremma.) 
Based on the current corn seed rates in Greece (180 $€ \mathrm{t}^{-1}$ ), the obtained yield increase ( 2 tons economic product) corresponds to $360 €$ ha $^{-1}$ which largely exceeds the overall cost of feed pea cultivation and incorporation (about $150 € \mathrm{ha}^{-1}$ ).

\section{Discussion}

The experimental soil (Table 2) is slightly calcareous, with a high CEC in both depths and a higher SOC and SOM and Ntot contents in the surface horizon, Ap. It is characterized by clay texture and during the dry period the formation of cracks causes problems in irrigation, tillage, and management of fertilizers.

The total nitrates inputs from irrigation varied substantially among treatments and ranged between 10.2 and $27.4 \mathrm{~kg} \mathrm{~N} \mathrm{ha}^{-1}$ (Table 3). In practice, irrigation water containing nitrate can supply nitrogen to the crops since it is applied and taken up during the growing period. Hence, nitrates content should be taken into account to accurately calculate the required nitrogenous fertilizers.

Results of the laboratory determinations concerning the incorporated material have indicated that green manuring contributes significantly to increasing of plant available macronutrients. The incorporated quantity of nutrients was found to the following decreasing order: $\mathrm{K}>\mathrm{N}>\mathrm{P}$. In particular, the amount of both elements $\mathrm{N}$ and $\mathrm{K}$ can be up taken from the succeeding crops, after mineralization.

The positive effect of incorporated pea to maize yield under full irrigation was highlighted by Skoufogianni et al. (2013). This was attributed to the improved topsoil physical properties and to considerable amounts of $\mathrm{N}$ being taken up by maize plants after mineralization. Field experiments were carried out to determine decomposition patterns of residues from various crops. It was revealed that crop residue exceeds $6.05 \mathrm{t} \mathrm{ha}^{-1}$ for feed pea and the extent of dry matter (DM) de- composition was usually lower under zero than under conventional tillage, e.g. corresponding percentages residues under conventional tillage, was: $55 \%$ for feed pea (Lupwayi et al., 2004). It was also found that residues left on the soil surface under zero tillage decomposed more slowly than those incorporated into the soil under conventional tillage. Rapid decomposition is not necessarily desirable because the nutrients released, especially nitrates, are subject to losses from the soil through the process of leaching. However, nitrogen can be mineralized rather rapidly and part of requirements of corn can be covered by $\mathrm{N}$ originated from plant residues, after mineralization by soil micro-organisms. Since P and K are relatively stable in soil, their losses by leaching are very low and crop can acquire part of these elements by means of mineralization.

Results from field experiments with common green manure legumes performed in North Europe, have shown that 114-196 kg N, 17-24 kg P and 89-144 kg $\mathrm{K} \mathrm{ha}^{-1}$ were returned to soil every year (Talgre et al., 2012). Experiments conducted in Chile have indicated that the main source of $\mathrm{N}$ input in soils was from $\mathrm{N}$ mineralization, while the contribution of rainfall and biological fixation to the total $\mathrm{N}$ inputs was less than 17\% (Lobos et al., 2016).Investigations to evaluate soil mineral nitrogen $(\mathrm{N})$ in agricultural fields have shown that $(0-100 \mathrm{~cm}$ depth) the history of organic matter application and other field management practices drastically affected the amount of mineral soil nitrogen (Fueki et al., 2010).

Plots receiving moderate to full irrigation exhibited considerably higher biomass and seed yield in comparison to the stressed plants (Table 4 and Figure 1). These results provide clear evidence that potential production could be attainable even with the moderate irrigation input $(66 \% \mathrm{ETm})$ resulting in a higher water use efficiency, e.g. $3.33 \mathrm{vs} 2.20 \mathrm{~kg}_{\text {grain }} \mathrm{t}^{-1} \mathrm{ir}-$ rigation water. This may be attributable to the initial 
soil water storage as well as the high water holding capacity of the studied clay soil which is important for saving large amounts of irrigation water for obtaining maximum corn yields. Benjamin and Nielsen (2006) observed that water deficit affects the distribution of pea roots under irrigated conditions, and about $80 \%$ of the field pea roots were in the top soil. It can be argued that the experimental area of University of Thessaly, is characterized by water shortage, and autumn sowing provides an opportunity to decrease the negative effects of water stress on grain pea yield.

As the moderate irrigation scheme could ensure maximum yield production of the traditionally managed corn (without green manure), it can be concluded that the increased yield and dry biomass in the green manured plots must be attributed to the improvement of the physical soil properties, the improved of watersoil relations and the more efficient uptake of water from the root zone, i.e. the same reasons for increasing water use efficiency. Similar positive effects of green manure on bulk density (5\% decrease) and total soil porosity ( $8 \%$ increase) in Inceptisols with low SOM soon after receiving green manure (Sultani et al., 2007). A very important finding comprises the significant increase in corn seed yield (as well as total biomass production) in the plots which had received green manure before the sowing of corn. Experiments conducted in Greece and Italy have indicated that the leguminous green manure has a dominant key role in managing the $\mathrm{N}$ soil fertility (Bilalis et al., 2012; Ciaccia et al., 2017) in the short period of experimentation. However, results from field experiments conducted in Greece to determine the effects of green manure on yield of maize (Bilalis et al., 2012) have shown that biomass was higher in faba bean (Vicia faba L.) and vetch (Vicia sativa L.) compared to pea (Pisum sativum L.), and both accumulated significantly more $\mathrm{N}$ than pea. Also, the lowest yield was recorded in the plots where pea was used as green manure.
However, appropriate incentives, management strategies, and yield benefit expectations should be fostered to increase the adoption potential of this N-economizing soil and water conservation strategy (O'Dea et al., 2013). As these are preliminary results of the first year of growing and incorporating feed pea as green manure before the establishment and growing of corn as main crop, the above economic incentive is expected to be much greater in the subsequent years of such practice through the continuous improvement of the soil structure and fertility.

\section{Conclusions}

The quantity of dry biomass of incorporated field pea was 5.2 tones $\mathrm{ha}^{-1}$ and nutrients originated from plant residues were found to the following order, such as: $\mathrm{K}>\mathrm{N}>\mathrm{P}$, respectively. The incorporated plant residues as green manure, increased plant available macronutrients, in particular K and N. Irrigation significantly affected corn growth and the final plant height was similar for both, full and moderate irrigation treatments, while the stressed plants had lower height.

A sizeable increase in corn yield was recorded in plots which had received green manure before the cultivation of Zea mays L. As the moderate irrigation scheme could ensure maximum productivity of corn without green manure, it can be argued that the increased yield and dry biomass in the plots where green manure was applied, must be attributed mainly to the improvement of soil properties.

The importance of feed pea cultivation as cover crop and the incorporation of its biomass, rich in NK nutrients as green manure was evidenced already in the first year of application on the yield and dry biomass production of a subsequent corn cultivation. In particular, this practice may increase the production potential of traditional corn monocultures in Central Greece (Thessaly) by $2 \mathrm{t} \mathrm{ha}^{-1}$ grain and by 3.3-3.8 $\mathrm{tha}^{-1}$ dry biomass. 
Hence, green manure as a practice may significantly increase farm profit. In addition, application of green manure can improve water use efficiency, physicochemical and biological soil properties. Therefore, the above practice should be seriously considered to be introduced in crop rotation systems in the immediate future in Greece and more generally on Mediterranean lowlands, where intensive monocultures are blamed for pronounce degradation of soils and production potentials

\section{Acknowledgments}

The present work has been carried out in the frame of the $\mathrm{PhD}$ research of the first author in the Laboratory of Agronomy and Applied Plant Physiology, Department of Agriculture Crop Production and Rural Environment, School of Agricultural Sciences, University of Thessaly, Greece. The authors express their very great appreciation to Dr Ch. Papanikolaou, member of the scientific staff of the Laboratory of Agricultural Hydraulics, School of Agricultural Sciences, University of Thessaly, for his valuable assistance in elaborating the meteorological data analysis.

\section{References}

Benjamin, J.G., Nielsen, D.C. 2006. Water deficit effects on root distribution of soybean, field pea and chickpea. Field Crop Res. 97:258-253.

Bilalis D., Karkanis, A., Sidiras, N., Travlos, I., Efthimiadou, A., Thomopoulos, P., Kakabouki, I. 2012. Maize and legumes root growth and yield as influenced by organic fertilization, under Mediterranean environmental conditions. Rom. Agric. Res. 29:211-217
Boquet, D.J., Dabney S.M. 1991. Reseeding, biomass, and nitrogen content of selected winter legumes on grain sorghum culture. Agron. J. 83:144-148.

Bremer, J.M. 1960. Determination of nitrogen in soil by Kjedahl method. J Agric. Sci. 55: 1-23.

Ciaccia C., Ceglie, F., Tittarelli, F., Antichi, D., Carlesi, S., Testani, E., Canali, S. 2017. Green manure and compost effects on N-P dynamics in Mediterranean organic stockless systems. J. Soil Sci. Plant Nut. 17: 751-76.

El Titi, A., Landes, H. 1990. Integrated farming system of Lautenbach: a practical contribution toward sustainable agriculture in Europe. In Edwards, C. et al. eds. Sustainable Agricultural Systems. Soil and Water Conservation Society, Ankeny, Iowa.

FAO, 1998. Crop evapotranspiration - Guidelines for computing crop water requirements - Irrigation and drainage paper 56 . Rome.

FAO, 2001. Carbon Sequestration for Improved Land Management. World Soil Resources Reports 96. Paris, France, 75 p.

FAO, 2010. Green Manure/Cover crops and rotation in conservation Agriculture on small farms, ISBN 978-92-5-106856-4.

FiBL, 2000. Organic Farming Enhances Soil Fertility and Biodiversity. Results from a 21 year field trial. Research Institute of Organic Agriculture (FiBL), Zurich.

Fueki N., Sato K., Nakatsu, S. 2010. Interpretation of soil mineral nitrogen by scoring organic matter and nitrogen management as an "N-score" in the fields of Hokkaido before sugar beet planting. J. Soil Sci. Plant Nut. 56: 750 - 759 .

Helming J., Kuhlman, T., Linderhof, V., Oudendag, D. 2014. Legume Futures Report 4.5 Impacts of legume-related policy scenarios. International research project funded by the EuroPisum sativum L.n Union through the Framework 7 Programme 
under grant agreement number 245216 (FP7-KBBE-2009-3).

Kaetterer T., Andrén, O. 1999. Long-term agricultural field experiments in $\mathrm{N}$ Europe: analysis of the influence of management on soil stocks using the ICBM model. Agric. Ecosys. and Environ. 72:165-179.

Lal, R. 1997. Residue management, conservation tillage and soil restoration for mitigating greenhouse effect by $\mathrm{CO}_{2}$ - enrichment. Soil Till. Res. 43: 81107.

Lobos, I., Alfaro, M., Martínez-Lagos, J. 2016. Soil nitrogen contribution to grasslands yield in southern Chile its implications for nitrogen use efficiency. J. Soil Sci. Plant Nut. 16: 310-322.

Lupwayi, N.Z., Clayton, G.W., O’Donovan, J.T., Harker, K.N., Turkington, T.K., Rice1, W.A. 2004. Decomposition of crop residues under conventional and zero tillage. Can. J. Soil Sci. 84:403-410.

Nelson, D.W., Sommers, L.E. 1973. Determination of total nitrogen in plant material. Agron. J. 65:10912.

O’Dea, J.K., Miller, R.P., Jones, C.A. 2013. Greening summer fallow with legume green manures: Onfarm assessment in north-central Montana. J. Soil Water Conserv. 68: 270-282.

Paustian, K., Elliot, E.T., Carter, M.R. 1998. Tillage and crop management impacts on soil $\mathrm{C}$ storage: use of long-term experimental data. Soil Till. Res. 47: 7-12.

Paustian, K., Elliot, E.T., Killian, K. 1998. Modeling soil carbon in relation to Management and climate change in some egro-ecosystems in Central America. In: Soil Processes and the Carbon Cycle. Lal, R., Kimble, J., Levine, E., Stewart, B.A. (eds). CRC Press. BocaRaton, FL. p. 459-471.
Payne, R.W., Harding S.A., Murray D.A., Soutar D.M., Baird, D.B., Glaser, A.I., Welham S.J., Gilmour A.R., Thompson R., Webster, R. 2011. GenStat Release 14 Reference Manual, VSN International, Hemel Hempstead, U.K.

Reganold, J.P., Elliott, L.F., Unger, Y.L. 1987. Longterm effects of organic and conventional farming on soil erosion. Nature. 330: 370-372.

Reicosky, D.C., Lindstrom, M.J. 1995. Impact of fall tillage on short-term carbon dioxide flux. In Lal, R., Kimble, J., Levine, E., Stewart, B.A. eds. Soils and global change. CRC Press.

Sakellariou-Makrantonaki, M., Vagenas, I. 2006. Mapping crop evapotranspiration and total crop water requirements estimation in Central Greece. European Water, pp. 3-13.

Skoufogianni, E., Danalatos, N.G., Dimoyiannis, D., Efthimiadis, P. 2013. Effects of Pisum sativum L. Cultivation as Cover Crop on Nitrogen-Use Efficiency and Nitrogen Uptake by Subsequent Maize and Sunflower Crops in a Sandy Soil in Central Greece. Commun. Soil Sci. Plan. Vol. 44, Iss. 1-4.

Smith, K.A. 1999. After the Kyoto Protocol: can soil scientists make a useful contribution? Soil Use Manage. 15:71-75.

Smith, P., Fallon, P., Coleman, K., Smith, J., Piccolo, M.C., Cerri, C., Bernoux, M., Jenkinson, D., Ingram, J., Szabo, J., Pasztor, L. 1999. Modeling soil carbon dynamics in tropical ecosystems. In Lal, R., Kimble, J., Levine, E., Stewart, B.A. eds. Global climate change and tropical ecosystems. Adv. Soil S., CRC Press, pp. 341-364.

Smith, P., Powlson, D.S., Glendenning, A.J., Smith, J.U. 1998. Preliminary estimates of the potential for carbon mitigation in EuroPisum sativum L.n soils through no-till farming. Glob. Change Biol. 4: 679-685. 
Sultani, M., Gill, M., Anwar, M., Athar, M. 2007. Evaluation of soil physical properties as influenced by various green manuring legumes and phosphorus fertilization under rain fed conditions. Int. J. Environ. Sci. Tech. 4:109-118.

Talgre, L., Lauringson, E., Roostalu, E., Astover, A., Makke, A. Green. 2012. Manure as a nutrient source for succeeding crops. Plant Soil Environ. 58: $275-281$

Tebruegge, F., Guring, R-A. 1999. Reducing tillage intensity - a review of results from a long-term study in Germany. Soil Till. Res. 53:15-28.
Tilman, D. 1998. The greening of the green revolution. Nature. 396, 211-212.

Wander, M., Bidart, M., Aref, S. 1998. Tillage experiments on depth distribution of total and particulate organic matter in 3 Illinois soils. Soil Sci. Soc. Am. J. 62:1704-11.

Working Group WRB. 2006. World reference base for soil resources. "World Soil Resources Reports No. 103”, FAO, Rome. ISBN 92-5-105511-4. 